\title{
JPEB
}

Jurnal Penelitian Ekonomi dan Bisnis, 5 (2), 2020, Hal: 136-151

http://www.jpeb.dinus.ac.id

\section{PATH ANALYSIS OF MONETARY POLICY MECHANISMS: DOES ECONOMIC CAPACITY MEDIATE PRICES?}

\author{
MG Westri Kekalih Susilowati ${ }^{*}$, Retno Yustini Wahyuningdyah ${ }^{2}$ \\ ${ }^{1,2}$ Management Study Program, Faculty of Economics and Business, Soegijapranata Catholic \\ University \\ Jalan Pawiyatan Luhur IV/1 Bendan Duwur Semarang 50234, Indonesia \\ *Corresponding Author: westriel@unika.ac.id
}

Received: February 2020; Revised: July 2020; Published: September 2020

\begin{abstract}
The single objective of Bank Indonesia is Rupiah's stability. Within the monetary policy framework, the monetary instruments affect the operational targets (money supply and interest rates). Those operational targets effect rupiah stability troughs its effect on economic capacity/GDP. Using 108 monthly data, that is analyzed by path analysis; this study discusses the effect of net foreign assets (NFA) and net domestic assets (NDA,) and interest rates on the prices (CPI) through their effects GDP. The results show that NFA and NDA have a significant positive effect on GDP, while interest rates are tended to be negative. However, neither the NFA nor the NDA has been proven to have a direct significant effect on CPI. The interest rate has been proven to have a direct significant effect on CPI. GDP was not proven to have a significant effect on the CPI and neither mediates the effects of operational targets on CPI.
\end{abstract}

Keywords: Rupiah; Prices; CPI; Stability; Money 


\section{INTRODUCTION}

The stability of Rupiah must be sought because it has a strategic role in the framework of improving community welfare efforts. The instability of rupiah affects prosperity through its influence on the purchasing power of society, economic growth, employment, and the health of the International Balance of Payment and other fundamental economies. Bank Indonesia has been pursuing general price control with various instruments with the target between interest rates and the amount of money supply. In the monetary policy framework, the money supply is affected by the net foreign assets (NFA) and net domestic assets (NDA) result of the implementation of both various monetary policy instruments and real sector policies like improving the investment climate. Therefore, knowledge of how NFA and NDA influence both directly and indirectly against prices is important. As to common has been known, the higher domestic prices compared to the prices in neighboring countries makes the domestic real interest rates uncompetitive to put pressure on the rupiah (Herlina, 2018; Rusiadi; Novalina \& Sembiring, 2017; Susilowati \& Wahyuningdyah, 2018). Besides the money supply, the operational target of monetary policy is interest rates (Jan Gottschalk, 2014; Machmud \& Warjoko, 2013; Sinaga \& Sudirman, 2018). Interest rates can affect economic capacity, credit channelings such as credit for investment, working capital, and consumption.

With the issuance of Law No. 23 of 1999 concerning Bank Indonesia, which was subsequently amended through Law No. 3 of 2004 and Law No. 6 of 2009 in article 7, Bank Indonesia has become an independent institution as a holder of the monetary authority in Indonesia. Based on the law, Bank Indonesia has a single target, that is achieving and maintaining the stability of the Indonesian Rupiah (IDR). The stability of Indonesian Rupiah (IDR) referred to in the law includes two dimensions, the stability the value of Indonesian Rupiah (IDR) and the exchange rate. The stability of the value of the Indonesian Rupiah (IDR) means the stability of the prices of goods and services reflected in the price index. Meanwhile, the exchange rate stability of Indonesian Rupiah (IDR) means the stability of Indonesian Rupiah (IDR) against other currencies. Since July 1, 2005, Bank Indonesia has implemented an Inflation Targeting Framework (ITF) in achieving that stability. Within ITF, the prices are the overriding objective.

Table 1. Money Supply and the Factors Affecting It

\begin{tabular}{|c|c|c|c|c|c|c|}
\hline Information & 2013 & 2014 & 2015 & 2016 & 2017 & $2018 *)$ \\
\hline Broad Money(M2) & $3,730,409$ & $4,173,327$ & $4,548,800$ & $5,004,977$ & $5,419,165$ & $5,529,452$ \\
\hline $\begin{array}{l}\text { Narrow Money } \\
\text { (M1) }\end{array}$ & 887,084 & 942,221 & $1,055,440$ & $1,237,643$ & $1,390,807$ & $1,384,265$ \\
\hline $\begin{array}{l}\text { Near Money or } \\
\text { Quasi-Money }\end{array}$ & $2,820,521$ & $3,209,475$ & $3,479,961$ & $3,753,809$ & $4,009,996$ & $4,128,708$ \\
\hline $\begin{array}{l}\text { Securities Other } \\
\text { Than Shares }\end{array}$ & 22,805 & 21,630 & 13,399 & 13,525 & 18,362 & 16,479 \\
\hline $\begin{array}{l}\text { Factors affecting } \\
\text { Money Supply }\end{array}$ & & & & & & \\
\hline $\begin{array}{l}\text { Net Foreign } \\
\text { Assets (NFA) }\end{array}$ & $1,011,361$ & $1,105,783$ & $1,176,638$ & $1,298,938$ & $1,541,838$ & $1,483,559$ \\
\hline $\begin{array}{l}\text { Bill on Non- } \\
\text { Residents }\end{array}$ & $1,442,896$ & $1,596,103$ & $1,741,211$ & $1,838,278$ & $2,073,389$ & $2,078,088$ \\
\hline $\begin{array}{l}\text { Obligations to } \\
\text { Non-Residents }\end{array}$ & 431,536 & 490,321 & 564,572 & 539,340 & 531,551 & 594,528 \\
\hline $\begin{array}{l}\text { Net Domestic } \\
\text { Assets (NDA) }\end{array}$ & $2,719,049$ & $3,067,544$ & $3,372,162$ & $3,706,039$ & $3,877,327$ & $4,045,892$ \\
\hline
\end{tabular}


MG Westri Kekalih Susilowati and Retno Yustini Wahyuningdyah: Path Analysis of Monetary Policy Mechanisms: Does Economic Capacity Mediate Prices?

\begin{tabular}{lrrrrrr}
\hline $\begin{array}{l}\text { Net Bill to The } \\
\text { Central } \\
\text { Government }\end{array}$ & 406,611 & 416,608 & 491,127 & 519,065 & 488,862 & 445,236 \\
$\begin{array}{l}\text { Bill to Other } \\
\text { Sectors }\end{array}$ & $3,526,612$ & $3,961,583$ & $4,318,126$ & $4,711,239$ & $5,087,392$ & $5,424,360$ \\
\hline$*)$ & Up to August & & & & & \\
\hline
\end{tabular}

The Indonesian economy as part of the world economy has entered the globalization era. The flow of resources across countries has become easier, including the flow of foreign investment. The better the investment climate in Indonesia is causing considerable incoming capital flows. The influx of foreign capital has led to an increase in net foreign assets (NFA) of monetary authorities, resulting in an increase in the amount of base money and NFAs of the monetary system. A study in Thailand also showed that domestic interest rates influenced the capital inflows into the country, also affecting the NFA (Jan Gottschalk, 2014). The positive effect of domestic interest rates on another path, the instrument of benchmark interest rate imposed by Bank Indonesia affects net domestic assets (NDA) through its effect on bills to the central government and bills to other sectors. Still referring to study in Thailand, it is discovered that interest rates are the cost of borrowing, have a direct impact on consumer spending (especially, on durable goods), housing and corporate investment, and determine savings/investment decisions (Jan Gottschalk, 2014). It means that NFA and NDA are the two main variables affecting the Money Supply in which it becomes an important determinant of prices.

Empirically, Money Supply has a positive effect on economic growth in Indonesia. Money supply affects economic growth in a country, directly or indirectly (Elies Nur Fauziyah, 2016; Prasasti, 2017; Rifai, Susanti, \& Setyaningrum, 2017; Wulandari \& Rahmadeni, 2017). Such conditions support the hypothesis proposed by Keynes, that money supply has a positive effect on aggregate supply which reflects economic capacity in which it will be equal to economic activity which includes consumption (C), investment (I), government expenditure $(\mathrm{G})$ and net exports $(\mathrm{X}-\mathrm{M})$. Further, the changes in economic capacity affect prices. However, the results of other studies showed that the growth of Money Supply, Gross Domestic Product (GDP), and the Interest Rate has no significant effect on prices (Parlembang, Krisnaldy, \& Ferdiansyah, 2017). Inflation is affected by Money Supply, World Oil Prices, Exchange Rate, and BI Rate. In contrast, some of the previous studies emphasizing the effect of monetary policy on price stability directly. Using the path analysis, this study explores the effect of Money Supply, consisting of Net Foreign Asset (NFA), Net Domestic Asset (NDA), and interest rates, on the prices with GDP as mediation. Determination of GDP as a mediator refers to the mechanism of monetary policy transmission, in which Money Supply and interest rates affect the ultimate objective of price stability through its effect on economic capacity.

\section{LITERATURE REVIEW}

\section{Inflation, Price Index, and Its Causing Factor}

Principally, inflation can be interpreted as a phenomenon of prices increase in which it happens continuously and within a certain period. The commonly used indicator to measure inflation is the change in Consumer Price Index (CPI), CPI is a figure reflecting the average price of goods and services consumed by households. Inflation is a change of CPI from time to time. In Indonesia, determining the types of goods and services used to calculate CPI is carried out based on a Cost of Living Survey (CLS) conducted by Statistics Indonesia (locally known as BPS). 
Prices are not only a monetary phenomenon but also a real phenomenon. As a real phenomenon, prices are the result of individual choices, and it affects the economy. At least two theories are analyzing the issue of prices, which are theories discussing prices as monetary phenomena only and inflation as real phenomena (real theory of inflation). Prices are one of the main issues discussed in the macroeconomy because of its great effect on economic life as a whole. The prices do not only concern on monetary matters, but it also contains social and political content. It can be seen from its influence on the redistribution of income in society and the political turmoil occurring as a result of high prices. Economic factors affecting the prices are the growth of the money supply set by the government (through the central bank/ Bank Indonesia) with the assumption that other things are constant. According to Irving Fisher, price $(\mathrm{P})$ is a function of money supply $(\mathrm{M})$. Mathematically, the relationship between price and money supply is formulated to be $\mathrm{P}=\mathrm{f}(\mathrm{M})$. Thus, it can also be said that the growth of the money supply determines the prices.

Related to various factors that influence the prices, some empirical studies have been carried out. Parlembang et al, (2017) examined the effect of the money supply, the growth of gross domestic product and the interest rate, as well as the USD exchange rate on prices, the error correction model (ECM) approach, is used. The results of the study showed that the effect of the money supply, the growth of the gross domestic product, and the interest rate does not significantly affect the prices. Of all the suspected variables affecting, only the USD exchange rate variable which is statistically proven to have a significant effect on the prices. Meanwhile, Panjaitan dan Wardoyo (2016) found that of the five variables allegedly influencing prices, the exchange rate and net exports were not statistically proven to have a significant effect on prices in Indonesia. However, together with the exchange rate, money supply, BI rate, and net exports affect prices in Indonesia (Hartomo, 2010; Langi et al, 2014; Sutawijaya, 2012). Meanwhile, the money supply, the exchange rate, and the fixed price individually have a positive and significant effect on prices in Indonesia. Whereas the interest rate has a positive, and it did not have a significant effect on influencing prices in Indonesia.

\section{The Stability of Indonesian Rupiah (IDR)}

The objective of Bank Indonesia according to Law No. 23 of 1999 concerning Bank Indonesia, subsequently amended through Law No. 3 of 2004 and Law No. 6 of 2009, is to achieve and maintain the stability of Indonesian Rupiah (IDR) (Bank Indonesia, 2017). The intended stability of Indonesian Rupiah (IDR) has two dimensions. The first dimension of the stability of Indonesian Rupiah (IDR) in the mean of the value that is reflected in the stability of the goods and services prices. The second dimension is related to the foreign exchange rate, rupiah against other countries' currencies. In the context of the foreign exchange rate, Indonesia adopts a free-floating system. The role of exchange rate stability is very important in achieving price stability and the financial system. Therefore, Bank Indonesia also runs a policy to maintain the stability of the exchange rate to match its fundamental value while maintaining the operation of the market mechanism.

To achieve the objective of maintaining the stability of the Indonesian Rupiah (IDR), Bank Indonesia adopted the Inflation Targeting Framework (ITF) since July 1, 2005. The policy framework is deemed by the mandate and institutional aspects mandated by the Law. Within this framework, the stability of prices is the overriding objective. Bank Indonesia consistently continues to have various improvements to the framework of monetary policy following changes in dynamics and occurred economic challenges to strengthen its effectiveness. In implementing monetary policy adhering to the framework called Inflation Targeting Framework (ITF), interest rates are used as operational targets. Before the adoption of the ITF, Bank Indonesia used monetary policies applying for base money as a target of monetary policy. 
Based on the experience of the global financial crisis that happened in 2008/2009, one important lesson emerging was the need for sufficient flexibility for the central bank to respond to increasingly complex economic developments. The financial sector is also expected to have a stronger role in influencing macroeconomic stability. Based on those developments, Bank Indonesia strengthened the ITF framework to be Flexible ITF. Flexible ITF is built by remaining based on the important elements of ITF having been built. The key elements of the ITF include the announcement of inflation targets to the public, monetary policies pursued in a forward-looking manner, and policy accountability to the public remains to be an inherent part of Flexible ITF. The Framework of Flexible ITF is built on 5 (five) main elements.

1. The stability of Prices is the single target of monetary policy.

2. Integrating monetary policy with macro-prudential policy to strengthen policy transmission and support macroeconomic stability.

3. Strengthening exchange rate policies and capital flows in supporting macroeconomic stability.

4. Strengthening policy coordination between Bank Indonesia and the Government both for price control and financial system stability.

5. Strengthening policy communication as part of policy instruments.

\section{Money Supply and Economic Capacity}

Money Supply can be defined as narrow money (M1) and broad money (M2). M1 includes currency held by the public and demand deposits (demand deposits denominated in Rupiah). Whereas, M2 includes M1, quasi money (including savings, long-term deposits in rupiah and foreign exchange, and demand deposits in foreign currencies), and securities issued by the monetary system. Several factors affecting money supply are Net Foreign Assets (NFA) and Net Domestic Assets (NDA). NDA consists of, among others, Net Claims on Central Government (NCCG) and claims to other sectors (the private sector, regional governments, financial institutions, and non-financial companies) in which they mainly are in the form of loans. The money supply is arranged concerning the Monetary and Financial Statistics Manual (MFSM) 2000 ("Monet. Financ. Stat. Man.," 2000).

Money has a very important role in the economy, both as an intermediary tool for exchanging, calculating units, and hoarding values. Therefore, the amount of money supply will certainly affect the economy. Based on classical monetary theory, Irving Fisher formulated the relationship between Money Supply and the economy with the formula MV = $\mathrm{PT}$, where $\mathrm{M}$ is Money supply, $\mathrm{V}$ is the speed of circulation or money circulation, $\mathrm{P}$ is the price, and $\mathrm{T}$ is the volume of transactions/trade (Dimand, 2000). The exchange equation was developed and expressed by an economist from Cambridge, Marshall, and Pigou, in different forms. Marshall and Pigou explained that the determination of the money value is as same as the determination of the money value in general, determined by demand and supply. In the cash-balance approach, Marshall and Pigou emphasized that the function of the money value as a hoarder is very different from the function of money as a money exchange in the Fisher transaction approach (Shiller, 2013). The cash-balance approach, mathematically formulated $\mathrm{M}=\mathrm{kPY}$, where $\mathrm{Y}$ is the aggregate output, $\mathrm{P}$ is the price ( $\mathrm{PY}$ is the value of aggregate output/GDP reflecting the economic capacity), $\mathrm{k}=$ the proportion of income in which people want to hold in the form of cash, and M is the Money supply. It means that GDP $=M / k$ by assuming the velocity of money circulation does not change, the increase of money supply will increase economic capacity. 


\section{RESEARCH METHODS}

This study was designed to examine the multiple relationships model between variables included in the framework of monetary policy regarding the effect of NFA, NDA, and interest rates on prices. Therefore, path analysis was a technique used in this study, in which it analyzes the NFA, NDA, and interest rates affecting the prices through its effect on GDP. Path analysis is intended to determine the relationship of direct dependency between a set of variables. Path analysis is a model similar to the multiple regression analysis models in terms of the causality relationship with differences in the level of complexity of the model. Regression analysis analyzes the dependent variable as the effect of the independent variable, but the dependent variable does not affect other dependent variables.

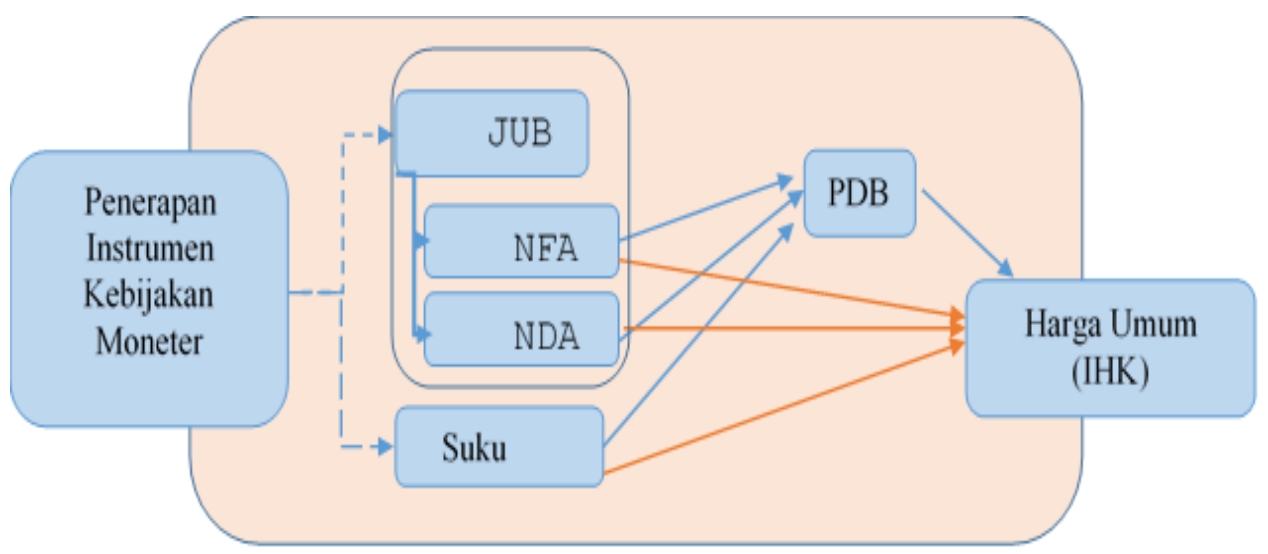

Figure 1. Research Framework

The development of empirical models in this study refers to the framework of monetary policy related to price control policy or price stability reflected in the Consumer Price Index (CPI). In terms of price control or price stability, Bank Indonesia as the holder of monetary authority has several instruments of monetary policy. The application of various monetary policy instruments does not always affect the final target of price stability, but it will affect the operational target of the money supply and interest rates. Furthermore, money supply and interest rates will affect economic activity consisting of public consumption expenditure (C), investment (I), government expenditure (G), and net exports (X-M) which are in equilibrium with economic capacity reflected in Gross Domestic Products (GDP). Economic capacity further affects the final target. In this study, the final target to be achieved is price stability reflected in the development of the CPI. The empirical model will then be transformed into an empirical model after undergoing data processing.

Starting from that framework of thinking, several working hypotheses can be arranged as follows:

1. $\mathrm{H}_{1}$ : NFA has a significant effect on GDP

2. $\mathrm{H}_{2}$ : NDA has a significant effect on GDP

3. $\mathrm{H}_{3}$ : Interest rate has a significant effect on GDP

4. $\mathrm{H}_{4}$ : NFA, NDA, Interest rate simultaneously has a significant effect on GDP

5. $\mathrm{H}_{5}$ : NFA has a significant effect on prices (CPI)

6. $\mathrm{H}_{6}:$ NDA has a significant effect on prices (CPI)

7. $\mathrm{H}_{7}$ : Interest rate has a significant effect on prices (CPI)

8. $\mathrm{H}_{8}:$ GDP has a significant effect on prices (CPI)

9. $\mathrm{H}_{9}$ : NFA has a significant effect on prices with GDP as mediation

10. $\mathrm{H}_{10}$ : NDA has a significant effect on prices with GDP as mediation

11. $\mathrm{H}_{11}$ : NDA has a significant effect on prices with GDP as mediation 
Equation of the Proposed Empirical Model:

1. GDP $=b_{0}+b_{1} N F A+b_{2} N D A+b_{3} I R+e 1$

2. CPI $=b_{0}{ }^{6}+b_{1}{ }^{\prime} \mathrm{NFA}+\mathrm{b}_{2}{ }^{\prime} \mathrm{NDA}+\mathrm{b}_{3}{ }^{\prime} \mathrm{IR}+\mathrm{b}_{4} \mathrm{GDP}+\mathrm{e} 2$

Information:

GDP = Empirical Economic Capacity/Gross Domestic Product

NFA $\quad=$ Net Foreign Asset

NDA $\quad=$ Net Domestic Asset

IR $\quad=$ Interest Rate

$\mathrm{b}_{0}{ }^{6} \quad=$ Constanta

$\mathrm{b}_{1}{ }^{\prime}, \mathrm{b}_{2}, \mathrm{~b}_{3}, \mathrm{~b}_{4}=$ regression coefficient;

$\mathrm{e}_{1}=$ error 1 ,

$\mathrm{e}_{2}=$ error 2

To get Best Linear Unbiased Estimator (BLUE), an empirical test was developed to meet the requirements of the classic assumption test applied in this study, which are the normality test, autocorrelation test, and multidisciplinary test on each developed empirical model.

\section{Mediator Variables Testing:}

1. $\mathrm{e}=1-\mathrm{R}^{2}$

2. The steps in testing a hypothesis refer to the procedure of testing the role of a mediator with SPSS:

1) Creating a regression equation of NFA $\left(X_{1}\right)$, NDA $\left(X_{2}\right)$, and Interest Rate $(X 3)$ on Economy Capacity/GDP $\left(\mathrm{Y}_{1}\right)$. From this regression analysis, it will produce a coefficient of $b_{1}, b_{2}$, and $b_{3}$. On that path, $b_{1}, b_{2}$, and $b_{3}$ expected to be significant ( $p$ $<0.05$ ) and meet classical assumptions. If it does not meet the classical assumption, the disease in the classic assumption is treated to be continued until the next analysis phase.

2) Creating a regression equation of NFA, NDA, Interest Rates, and GDP against CPI. From this regression analysis, it will produce coefficients $b_{1}{ }^{\prime}, b_{2}{ }^{\prime}, b_{3}{ }^{\prime}$, and $b_{4}{ }^{\prime}$. These paths $b_{1}{ }^{\prime}, b_{2}{ }^{\prime}, b_{3}$ ', and $b_{4}$ ' are expected to be significant $(p<0.05)$. As in the regression equation 1 , the regression equation 2 is also expected to meet the classical assumptions, and if it does not meet the classical assumptions, the disease in the classic assumptions is treated to be continued at the analysis stage

If the regression equation $1 b_{1}, b_{2}$, and $b_{3}$ are expected to be significant ( $p<0.05$ proved significant ( $p<0.05$ ), so are the coefficients $b_{1}{ }^{\prime}, b_{2}{ }^{\prime}, b_{3}{ }^{\prime}$ and $b_{4}{ }^{\prime}$ in the regression equation 2 . Therefore, it can be concluded that GDP is a mediating variable or is a mediator of the effect of money supply and interest rates on price stability reflected in the CPI.

\section{RESULT AND DISCUSSION Empirical Model 1}

The empirical model 1 developed starts from the hypothesis that the intermediate target of monetary policy, in which the money supply and interest rates directly affect the economic capacity reflected in the Gross Domestic Product (GDP). By using a histogram, it can be seen that the distribution on the left and right sides of the standardized residual regression curve for empirical model 1 is quite symmetrical. The classic assumption test on model 1 showed that the empirical model 1 developed has a normally distributed regression residual. This condition is reflected in the statistical test value known to 0.054 with Asymp. Sig. (2-tailed) of 0,200 is greater than 0.00. The results of the Durbin Watson auto-correlation 
test showed that the empirical model 1 was free of auto-correlation symptoms with the D-W test of 2.022> 1.96 (table 1). The empirical model 1 proposed is also free from the multicollinearity phenomenon reflected in the tolerance value which is greater than 0.10 and the VIF value less than 10 (table 2). Thus, the empirical model 1 meets the BLUE requirements and can be further analyzed. The empirical model 1 proposed is (equation 1):

$$
\left.\mathrm{GDP}=\mathrm{b}_{0}+\mathrm{b}_{1} \mathrm{NFA}+\mathrm{b}_{2} \mathrm{NDA}+\mathrm{b}_{3} \mathrm{IR}+\mathrm{e} 1 \ldots \ldots \ldots \ldots \ldots \ldots . . . \ldots \text { (equation } 1\right)
$$

Table 2. Durbin-Watson Test in Empirical Model 1

\begin{tabular}{lrrrrr}
\hline Model & R & R Square & $\begin{array}{c}\text { Adjusted } \\
\text { R Square }\end{array}$ & $\begin{array}{r}\text { Std. Error } \\
\text { of the } \\
\text { Estimate }\end{array}$ & Durbin-Watson \\
\hline 1 & $.996^{\mathrm{a}}$ & .992 & .992 & .00875 & 2.022 \\
\hline
\end{tabular}

a. Predictors: (Constant), IR, NFA, NDA

b. Dependent Variable: GDP

Table 3. Multicollinearity Test in Empirical Model 1

\begin{tabular}{lrr}
\hline Model & \multicolumn{2}{c}{ Collinearity Statistics } \\
\cline { 2 - 3 } & Tolerance & VIF \\
\hline (Constant) & & \\
NFA & .215 & 4.652 \\
NDA & .192 & 5.209 \\
IR & .418 & 2.390 \\
\hline
\end{tabular}

a. Dependent Variable: GDP

Table 4. Regression Coefficient of Empirical Model 1

\begin{tabular}{|c|c|c|c|c|c|}
\hline \multirow[t]{2}{*}{ Model } & \multicolumn{2}{|c|}{$\begin{array}{l}\text { Unstandardized } \\
\text { Coefficients }\end{array}$} & \multirow{2}{*}{$\begin{array}{r}\begin{array}{r}\text { Standardized } \\
\text { Coefficients }\end{array} \\
\text { Beta }\end{array}$} & \multirow[t]{2}{*}{$\mathbf{T}$} & \multirow[t]{2}{*}{ Sig. } \\
\hline & $\mathbf{B}$ & Std. Error & & & \\
\hline (Constant) & .609 & .049 & & 12.383 & .000 \\
\hline NFA & .051 & .014 & .129 & 3.664 & .000 \\
\hline NDA & .089 & .004 & .780 & 20.946 & .000 \\
\hline IR & -.015 & .003 & -.115 & -4.565 & .000 \\
\hline
\end{tabular}

a. Dependent Variable: GDP

The empirical model 1 proved that NFA and NDA statistically have positive and significant effects on GDP, while IR has a negative effect. This phenomenon is consistent with research conducted by (Machmud \& Warjoko, 2013; Prasasti, 2017; Pratiwi, Kristianti, \& Mahardika, 2016). Referring to table 4, it means that each rupiah increase in NFA will cause GDP to rise by 0.051 rupiahs; each rupiah increase in NDA will cause GDP to rise by 0.089 rupiahs; and each percent of the increase in interest rates will cause an economic contraction of 0.015 percent. NFA. The economic capacity that is not affected by NFA, NDA, and interest rates of IDR 609 trillion. NFA, NDA, and interest rates together significantly affect GDP with prob sig. of 0,000. Model 1 has a coefficient of determination (R2) of 0.972. It means that NFA, NDA, and IR affect the economic capacity of 97.2 percent, while 2.8 percent of GDP is affected by other variables outside the model. This finding is supported by research conducted by Budi Prasasti, Karari (2017). 


\section{Empirical Model 2}

Empirical model 2 was developed as part of the GDP variable testing step as a mediator of the effect of NFA, NDA, and interest rates on CPI as the final target. The development of the empirical model 2 is based on the hypothesis that in addition to having a direct effect, the intermediate target of monetary policy, in which money supply and interest rates affect the CPI through its effect on economic capacity reflected in the Gross Domestic Product (GDP).

CPI

$$
=b_{0}{ }^{6}+b_{1}{ }^{\prime} N F A+b_{2}{ }^{\prime} N D A+b_{3}{ }^{\prime} I R+b_{4} G D P+e 2
$$

The normality test in the empirical model 2 showed that the distribution histograms on the left and right sides of the standardized residual regression curve are quite symmetrical (figure 4.4). Likewise, the test results are statistically using the Kolmogorov-Smirnov approach. As presented in table 4.6, the statistical test values are known to be 0.065 with Asymp. Sig. (2-tailed) of 0,200 is greater than 0.05. It means that the classic assumption of normality is accepted.

Table 5. One-Sample of Kolmogorov-Smirnov Test in Empirical Model 2

\begin{tabular}{llr}
\hline & & $\begin{array}{r}\text { Unstandardized } \\
\text { Residual }\end{array}$ \\
\hline $\mathrm{N}$ & & 108 \\
Normal Parameters & Mean & .0000000 \\
Most Extreme Differences & Std. Deviation & .00939814 \\
& Absolute & .065 \\
& Positive & .063 \\
Test Statistic & Negative & -.065 \\
Asymp. Sig. (2-tailed) & & .065 \\
\hline Test & & $.200^{\text {c.d }}$ \\
\hline
\end{tabular}

a. Test distribution is Normal.

b. Calculated from data.

c. Lilliefors Significance Correction.

d. This is a lower bound of the true significance.

The auto-correlation test in empirical model 1 showed the existence of positive autocorrelation symptoms. It is reflected in the results of the Durbin-Watson test calculation of 0.490 which is smaller than the DL on the number of variables $(\mathrm{k})=5$, and the number of samples (n) of 108 amounted to 1.610412 and (4-DW) of 3.51 greater compared to DU of 1.74372 (table 6).

Table 6. Durbin-Watson Test in Empirical Model 2

\begin{tabular}{lrrrrr}
\hline Model & R & R Square & $\begin{array}{r}\text { Adjusted R } \\
\text { Square }\end{array}$ & $\begin{array}{r}\text { Std. Error } \\
\text { of the } \\
\text { Estimate }\end{array}$ & $\begin{array}{r}\text { Durbin- } \\
\text { Watson }\end{array}$ \\
\hline 1 & $.781^{\text {a }}$ & .611 & .596 & .05328 & .490 \\
\hline
\end{tabular}

a. Predictors: (Constant). GDP IR NFA. NDA

b. Dependent Variable: CPI

Violations of the classical assumptions do not have auto-correlation indeed tending to be found in periodic series data. It is because the value of a t-variable can be affected by the value of the lag variable, for example, the value of variables at $\mathrm{t}-1, \mathrm{t}-2$, and so on. 


\section{Multicollinearity Test in Empirical Model 2}

The existence of violations of the classic multi-collinearity assumption is based on a tolerance value greater than 0.10 and a VIF value less than 10. Based on the results of the regression calculation in the empirical model 2, it is known that there is a violation of the classical assumptions because multi-collinearity symptoms are found. It reflects both based on the tolerance value in the NDA and GDP variables, as well as the VIF value on these variables. The tolerance value on the NDA variable is 0.037 smaller than 0.10 , so is the tolerance value on the variable GDP of 0.028 . Seen from the VIF value, the VIF values of NDA and GDP have values greater than 10, respectively 27.185 and 36.130 .

Table 7. Multicollinearity Test in Empirical Model 2

\begin{tabular}{lrr}
\hline Model & \multicolumn{2}{c}{ Collinearity Statistics } \\
\cline { 2 - 3 } & Tolerance & VIF \\
\hline (Constant) & & \\
NFA & .190 & 5,252 \\
NDA & .037 & 27,185 \\
IR & .349 & 2,869 \\
GDP & .028 & 36,130 \\
\hline
\end{tabular}

a. Dependent Variable: CPI

Because there are violations of the assumption of auto-correlation and multi-collinearity, "treatment" is needed to obtain a BLUE estimation model.

\section{Empirical Model 3}

Empirical model 3 was developed to improve empirical model 2. The existence of auto-correlation is suspected due to the effect of the lag of variable usually occurring in time series data. Therefore, empirical model 3 was developed by including the variable of lag_CPI, i.e. the CPI period $t$ is also affected by the previous period CPI ( $\mathrm{t}-1)$. Equation of empirical model 3 can be written (equation 3)

$\mathrm{CPI}=\mathrm{b}_{0}{ }^{{ }}+\mathrm{b}_{1}{ }^{\prime} \mathrm{NFA}+\mathrm{b}_{2}{ }^{\prime} \mathrm{NDA}+\mathrm{b}_{3}{ }^{\prime}{ }^{\prime} \mathrm{IR}+\mathrm{b}_{4} \mathrm{GDP}+\mathrm{b}_{5}$ Lag_CPD $+\mathrm{e} 3 \ldots . . .($ equation 3$)$

Where GDP: Economy Capacity; NFA: Net Foreign Asset; NDA: Net Domestic Asset, Lag_CPI: CPI period t-1, $\mathrm{b}_{0}{ }^{6}:$ Constanta, $\mathrm{b}_{1}{ }^{\prime}, \mathrm{b}_{2}{ }^{\prime}, \mathrm{b}_{3}, \mathrm{~b}_{4}, \mathrm{~b}_{5}$. Regression coefficient $\mathrm{e}_{3}$ : error 3 Statistical normality test results using the Kolmogorov-Smirnov approach with a statistical test value of 0.098 with Asymp. Sig. (2-tailed) of 0,065 is greater than 0.05. It means that empirical model 3 meets the classic assumption of normality.

Table 8. One-Sample of Kolmogorov-Smirnov Test in Empirical Model 3

\begin{tabular}{|c|c|c|}
\hline & & Smothered \\
\hline $\mathrm{N}$ & & 108 \\
\hline \multirow[t]{2}{*}{ Normal Parameters ${ }^{\mathrm{b}}$} & Mean & .002272 \\
\hline & Std. Deviation & .0042205 \\
\hline \multirow[t]{3}{*}{ Most Extreme Differences } & Absolute & .098 \\
\hline & Positive & .052 \\
\hline & Negative & -.098 \\
\hline Test Statistic & & .098 \\
\hline Asymp. Sig. (2-tailed) & & $.065^{\circ}$ \\
\hline
\end{tabular}


a. Test distribution is Normal.

b. Calculated from data.

c. Lilliefors Significance Correction.

Based on the Durbin-Watson table, for $\mathrm{K}$ is equal to 6, and the number of observations 108 has dL of 1.59087 and dU 1.78412. The Durbin-Watson test for empirical model 3 in this study was 1,794 . Thus, the Durbin-Watson test for empirical model 3 in this study has a condition greater than $\mathrm{dU}$. It means that there is no positive auto-correlation, and (4-1704) equals 2.206 greater than $\mathrm{dU}$ meaning that there is no negative auto-correlation.

Table 9. Durbin-Watson Test in Empirical Model 3

\begin{tabular}{lrrrrr}
\hline Model & R & R Square & $\begin{array}{r}\text { Adjusted R } \\
\text { Square }\end{array}$ & $\begin{array}{r}\text { Std. Error } \\
\text { of the } \\
\text { Estimate }\end{array}$ & $\begin{array}{r}\text { Durbin- } \\
\text { Watson }\end{array}$ \\
\hline 1 & $.915^{\mathrm{a}}$ & .837 & .829 & .03459 & 1,794 \\
\hline
\end{tabular}

a. Predictors: (Constant). LagCPI. NFA. IR NDA. GDP

b. Dependent Variable: CPI

The results of the statistical calculation of collinearity in the empirical model 3 still show the presence of multi-collinearity symptoms. This condition is reflected in the tolerance value smaller than 0.10 in the NDA and GDP variables, and the VIF is greater than 10 in both of these variables. The tolerance value of the NDA variable is 0.37 , while the tolerance value for the GDP variable is 0.026. Collinearity statistics of VIF show a figure of 26,964 in NDA variables and 38,714 in the GDP variable.

Table 10. Multicollinearity Test in Empirical Model 3

\begin{tabular}{lrr} 
& \multicolumn{2}{c}{ Collinearity Statistics } \\
\cline { 2 - 3 } (Constant) & Tolerance & VIF \\
\cline { 2 - 3 } NFA & & \\
NDA & .192 & 5,205 \\
GDP & .037 & 26,964 \\
IR & .026 & 38,714 \\
LagCPI. & .138 & 7,248 \\
\hline
\end{tabular}

a. Dependent Variable: CPI

Although there is multi-collinearity, empirical model 3 will still be used with the assumption that all independent variables together have a significant effect on CPI. It is reflected in the F-Sig probability value of 0,000 (table 4.13).

Table 11. Regression Coefficient of Empirical Model 3

\begin{tabular}{lrrrrr}
\hline & \multicolumn{3}{c}{ Unstandardized Coefficients } & \multicolumn{3}{c}{ Unstandardized Coefficients } \\
\cline { 2 - 6 } & $\mathbf{B}$ & Std. Error & Beta & $\mathbf{t}$ & Sig. \\
\hline (Constant) & .775 & .294 & & 2,636 & .010 \\
NFA & -.022 & .030 & -.068 & -.739 & .462 \\
NDA & -.001 & .020 & -.012 & -.056 & .956 \\
IR & -.031 & .012 & -.273 & $-2,524$ & .013 \\
GDP & -.096 & .211 & -.113 & -.453 & .651 \\
LagCPI. & .773 & .065 & .774 & 11,819 & .000 \\
\hline
\end{tabular}


Regarding the effect of variables of NFA, NDA, IR, GDP, and lagCPI on CPI, it can be explained that NFA, NDA, and GDP do not have a direct effect on CPI, which is each with a probability value of Sig. partial by 0,$462 ; 0.956$ and 0.651 . Meanwhile, the other two variables, interest rates (IR) and period t-1 CPI (lagCPI) have a direct and significant effect on the CPI. Interest rates have a negative effect of 0.031 on the CPI with a Sig. 0.013, and LagCPI has a positive effect of 0.773 with Sig. 0.000 .

Table 12. Durbin-Watson Test in Empirical Model 3

\begin{tabular}{lrrrrr}
\hline Model & $\begin{array}{r}\text { Sum of } \\
\text { Squares }\end{array}$ & df & $\begin{array}{r}\text { Mean } \\
\text { Square }\end{array}$ & F & Sig. \\
\hline Regression & .622 & 5 & .124 & 103,947 & $.000^{\mathrm{b}}$ \\
Residual & .121 & 101 & .001 & & \\
Total & .743 & 106 & & & \\
\hline
\end{tabular}

a. Dependent Variable: CPI

b. Predictors: (Constant). LagCPI. NFA. IR NDA. GDP

Source: Bank Indonesia, processed 2019

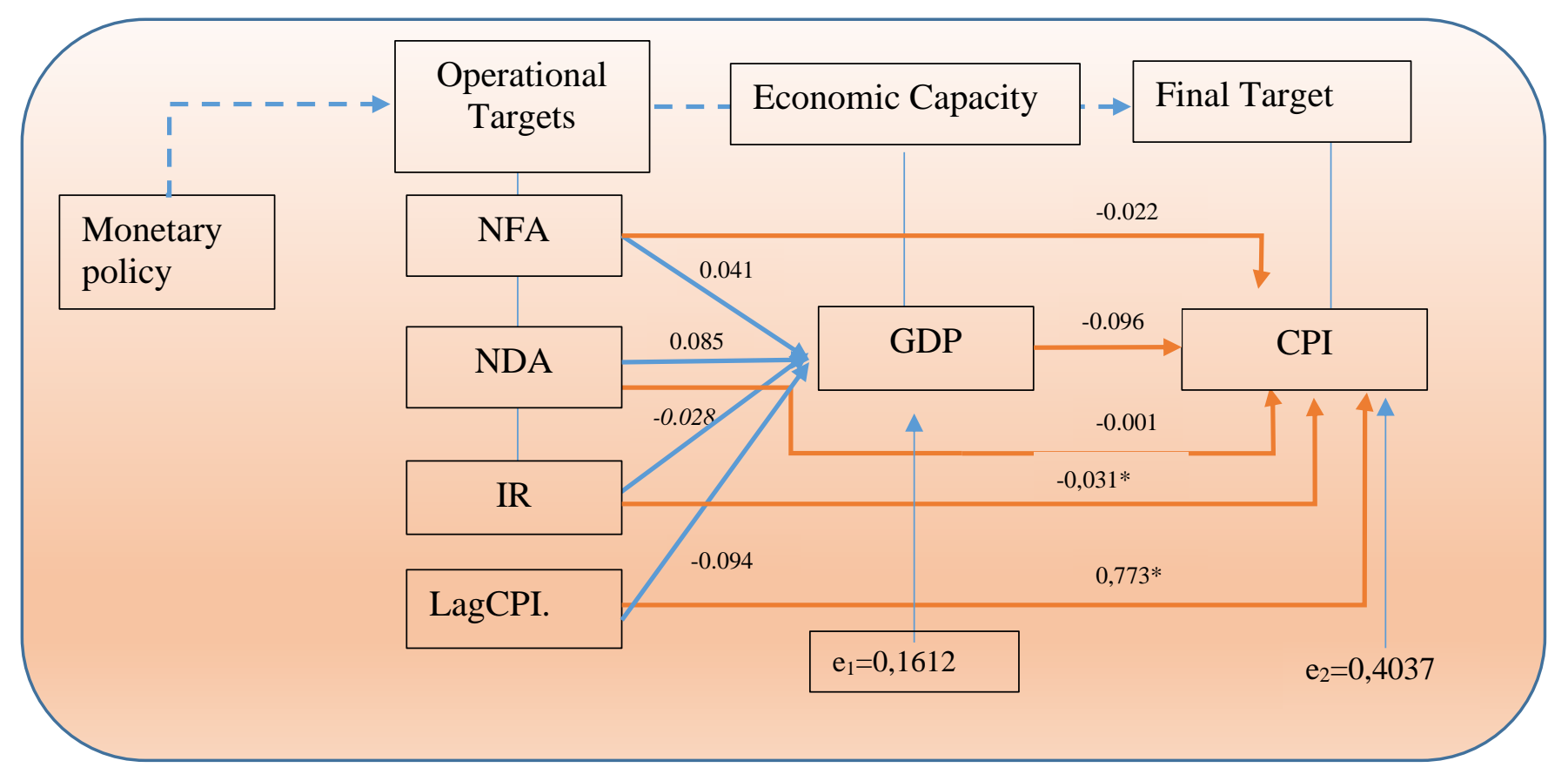

Figure 2. Path Analysis of the Effect of NFA, NDA, and IR on CPI with GDP as Mediation Variables

\section{Mediating Variables, GDP, Testing:}

\section{Step 1}

Empirical Model 1, with the regression equation of NFA. NDA. Interest rate and lagCPI against Economic capacity/GDP (Y1) result in significant coefficients $b_{1}, b_{2}, b_{3}$, and $b_{4}$ at alpha $=0.05(\mathrm{p}<0.05)$, and it meets classical assumptions.

\section{Step 2}

Empirical Model 3, with the regression equation of NFA, NDA, Interest Rates, LagCPI, and GDP against CPI. The regression coefficient of NDA of -0.001 was not significant at alpha 
0.05 with Sig. 0.956 . The regression coefficient of NFA of -0.022 was not significant at alpha 0.05 with Sig. 0.462. Likewise, the regression coefficient of GDP of -0.096 was not significant at alpha 0.05 with Sig. 0.651 . Two variables having been statistically proven to have a significant effect on alpha 0.05 against CPI are interest rates and lagCPI. Each has a regression coefficient of -0.031 and 0.0773 , with each having a Sig. 0.013 and 0,000. Empirical model 3 meets the requirements of classical assumptions.

\section{Step 3}

In the regression equation of empirical model 1 , the value of the regression coefficient of NFA, NDA, interest rate (IR), and CPI with a t-1 period (lagCPI) proved significant ( $p<0.05$ ). However, in the regression coefficients of NFA, NDA, interest rates (IR), and CPI with a t-1 period (lagCPI) and GDP in the regression equation of empirical model 3, there are only two beta values proved significant at alpha 0.05 , which were the regression coefficient of interest rate (IR) and lagCPI. Then, it can be concluded that GDP does not mediate the effect (not intervening variables) of NFA, NDA, interest rate (IR), and CPI with a t-1 period (lagCPI) on $\mathrm{CPI}$. To convince the conclusion that GDP does not mediate (include intervening variables) the effect of NFA, NDA, interest rates (IR), and CPI with a t-1 period (lagCPI) on CPI, a Sobel test is performed for each variable. The Sobel test results also showed that GDP is not a mediating variable. It is reflected in the results of the calculations of the Sobel test presented in Table 13.

Table 13. Sobel Test of the Effect of NFA, NDA, IR, and LagCPI on CPI with GDP as Mediation Variables

\begin{tabular}{lrrr}
\hline Variable & Sobel Test & Prob 1 Tail & Prob 2 Tail \\
\hline NFA & 1.3275 & 1.7846 & 0.8923 \\
NDA & 1.3453 & 2.3570 & 0.1785 \\
Interest Rate (IR) & -1.3380 & 2.3618 & 0.1809 \\
LagCPI. & 0.8799 & 0.7576 & 0.3788 \\
\hline
\end{tabular}

\section{Discussion}

Starting from the framework of monetary policy operations, this study formulates the hypothesis that the operational target of monetary policy, the money supply or interest rates, play a role in efforts to control prices through their effects on economic capacity or economic activity. Assuming measured economic capacity with the gross domestic product (GDP), it is hypothesized that GDP is a mediating variable or 'intervening variable' from the effect of operational targets on the money supply grouped in net foreign assets and net domestic assets and interest rates on price stability reflected in CPI. Upon this hypothesis, path analysis shows that:

1. NFA is statistically proven to have a significant effect on GDP

2. NDA is statistically proven to have a significant effect on GDP

3. Interest rate is statistically proven to have a significant effect on GDP

4. NFA, NDA, and Interest rate simultaneously have a significant effect on GDP

5. NFA is not statistically proven to have a significant effect on the Prices (CPI)

6. NDA is not statistically proven to have a significant effect on the Prices (CPI)

7. Interest rate is statistically proven to have a significant effect on Prices (CPI)

8. GDP is not statistically proven to have a significant effect on the Prices (CPI)

9. GDP is not statistically proven as mediating variable of NFA, NDA, and Interest rate against GDP 
In testing the model, estimation model 1, GDP, is a function of NFA, NDA, and Interest Rates meeting the classical assumptions. Therefore, the estimation model 1 can be determined as an empirical model 1 that can be the forecasting instrument which is Best Linear Unbiased Estimator (BLUE). However, when the model is simulated by making GDP as one of the independent variables and placing the CPI as a dependent variable, the classic assumption test shows the existence of auto-correlation. To overcome the existence of autocorrelation, a new variable was added to the model, which is the CPI with the t- 1 period (lagCPI), assuming that the CPI with the t period was affected by the CPI of the previous month. By adding the lagCPI variable, the auto-correlation problem can be overcome. The estimation model with the addition of the lagCPI variable is processed using a regression approach and is determined as an empirical model 3, which is the CPI is a function of the NFA, NDA, Interest Rates, GDP, and lagCPI.

Empirical model 3 showed that NFA, NDA, GDP do not have a significant effect on CPI, while interest rates and lagCPI are proven to have a significant effect on CPI. As it can be seen from the regression results, the money supply variable consisting of NFA and NDA has a positive value, but it has not been proven to have a significant effect, meaning that any increase in money supply will cause the increase of prices reflected in the CPI to rise. The effect of NFA and NDA on the prices that is not significant occurs because the money supply is the overall value of money in the community, and money in the bank is not counted as money in circulation. According to David Ricardo, the factor affecting CPI is the price level. For instance, when the prices of goods and services have increased, the CPI and the money supply will increase. Likewise, the results of this study do not prove the effect of GDP on the Prices, nor the GDP as a mediating variable, the effect of the money supply consisting of NFA and NDA on prices. The explanation above is that the CPI is used to measure the rate of price growth of an economy. The CPI reflects the average combined price of consumption. Thus, the CPI does not provide a complete picture of the aggregate expenditure of an economy. Therefore, prices in the production chain, future price pressures, and global competition are not included in the CPI.

\section{CONCLUSION}

With the mechanism of monetary policy transmission, monetary policy instruments affect the stability of prices reflected in the consumer price index (CPI) through the operational target of the money supply consisting of net foreign assets (NFA), net domestic assets (NDA), interest rates, as well as economic capacity. In this study, it was hypothesized that measured economic capacity with the gross domestic product (GDP) is a mediating variable or 'intervening variable' from the effect of operational targets on the money supply grouped in net foreign assets and net domestic assets, and the effect of interest rates on price stability reflected in CPI. By using periodic series data for 9 years or 108 months, this study showed that:

1. Net foreign assets and net domestic assets were statistically proven to have a significant positive effect on GDP, while interest rates have a negative effect.

2. Net foreign assets, net domestic assets, and interest rates were simultaneously proven to have a significant effect on GDP

3. Net foreign assets and net domestic assets are not statistically proven to affect Prices (CPI).

4. Interest Rates are statistically proven to have a significant effect on Prices (CPI)

5. GDP is not statistically proven to have a significant effect on Prices (CPI)

6. GDP is not proven statistically as a mediating variable of NFA, NDA, and interest rates to GDP.

Overall, the findings showed that GDP, which does not have a significant effect on prices are consistent with the theory developed by Milton Friedman saying that price 
stability/inflation is a monetary phenomenon so that the objective of achieving price stability is simply done by controlling the money supply.

The implication of managerial or policy starting from these findings is that operational interest rates are more effective if the focus of the ultimate objective is price stability. However, if the ultimate objective or goal is economic growth, the contribution of operational targets to the money supply consisting of net foreign assets and net domestic assets is more effective than a contribution to operational interest rates. Overall, the findings of this study reinforce the absence of a classical dichotomy, and Bank Indonesia as the holder of monetary authority also plays a large role in the stability of the real sector because the operational target of the money supply is proven to have a significant effect on economic capacity. It means that the operational target for the money supply can be a factor that can accelerate economic growth. The limitation of this study is that the path analysis only observes at the one-way relationship. Meanwhile, when discussing the relationship between monetary policy, interest rates, money supply, economic capacity, and price stability, empirically, there is a more complex relationship because the variables affect one another. Therefore, how the causality relationship between variables in the transmission of monetary policy will be an interesting research topic.

\section{REFERENCES}

Dimand, R. W. (2000). Irving Fisher and the Quantity Theory of Money: The Last Phase. Journal of the History of Economic Thought. https://doi.org/10.1080/10427710050122549

Elies Nur Fauziyah, W. (2016). Pengaruh Bi Rate Dan Jumlah Uang Yang Beredar Terhadap Tingkat Inflasi Di Indonesia. Jurnal Pendidikan Ekonomi (JUPE).

Hartomo, H. A. (2010). Pengaruh Jumlah Uang Beredar Dan Kurs Terhadap Tingkat Inflasi di Indonesia Sebelum Dan Setelah Krisis Global 2008. Media Ekonomi.

Herlina, D. (2018). Identifikasi Mekanisme Transmisi Kebijakan Moneter Saluran Uang dan Saluran Suku Bunga Di Indonesia. Jurnal Ekonomi-Qu. https://doi.org/10.35448/jequ.v8i2.4446

Indonesia, B. (n.d.). BI 7-day (Reverse) Repo Rate. Retrieved from https://www.bi.go.id/en/moneter/bi-7day-RR/penjelasan/Contents/Default.aspx

Jan Gottschalk, T. (2014). Monetary Transmission Mechanism: Workshop on Monetary and Exchange Rate Policy. Bangkok - Thailand: IMF.

Langi, T. M., Maisnambow, V., \& Siwu, H. (2014). Analisis pengaruh suku bunga BI, jumlah uang beredar, dan tingkat kurs terhadap tingkat inflasi diiIndonesia. Jurnal Berkala Ilmiah Efisiensi.

Machmud, S., \& Warjoko, B. A. (2013). Analisis Pengaruh Tingkat Inflasi, Nilai Tukar USD/Rupiah, Dan Tingkat Suku Bunga SBI Terhadap Indek Harga Saham Gabungan. Jurnal Ekonomi, Bisnis \& Entrepreneurship.

Monetary and Financial Statistics Manual. (2000). In the Monetary and Financial Statistics Manual. https://doi.org/10.5089/9781589060296.049

Panjaitan, M., \& Wardoyo, W. (2016). Faktor-Faktor yang Mempengaruhi Inflasi di Indonesia. Jurnal Ilmiah Ekonomi Bisnis.

Parlembang, H., Krisnaldy, \& Ferdiansyah, F. (2017). Pengaruh Jumlah Uang Beredar, Produk Domestik Bruto, Kurs Dan Tingkat Bunga Terhadap Inflasi Di Indonesia Pendekatan Error Corection Model. Media Ekonomi. https://doi.org/10.25105/me.v19i3.771

Prasasti, K. B. (2017). Pengaruh Jumlah Uang Beredar Terhadap Harga Umum dan Suku Bunga. Serta Terhadap Investasi dan Pertumbuhan Ekonomi Di Indonesia Periode 1973-2012. Thesis. Universitas Airlangga. 
Pratiwi, M. I., Kristianti, F. T., \& Mahardika, D. P. K. (2016). Pengaruh Kepemilikan Manajerial, Kepemilikan Institusional, Dan Leverage Terhadap Nilai Perusahaan. EProceeding of Management.

Rifai, S. A., Susanti, H., \& Setyaningrum, A. (2017). Analisis Pengaruh Kurs Rupiah, Laju Inflasi, Jumlah Uang Beredar dan Pertumbuhan Ekspor terhadap Total Pembiayaan Perbankan Syariah dengan Dana Pihak Ketiga sebagai Variabel Moderating. MUQTASID Jurnal Ekonomi Dan Perbankan Syariah. https://doi.org/10.18326/muqtasid.v8i1.18-39

Rusiadi; Novalina, A., \& Sembiring, R. (2017). Efektifitas Mekanisme Transmisi Kebijakan Moneter Melalui Jalur Suku Bunga terhadap Stabilitas Ekonomi Indonesia. JEpa.

Shiller, R. J. (2013). Irving Fisher, debt deflation, and crises. Journal of the History of Economic Thought. https://doi.org/10.1017/S1053837213000059

Sinaga, T. T., \& Sudirman, I. W. (2018). Mekanisme Transmisi Kebijakan Moneter Dalam Perekonomian Indonesia. E-Jurnal Ekonomi Dan Bisnis Universitas Udayana. https://doi.org/10.24843/eeb.2018.v07.i08.p04

Susilowati, M. W. K., \& Wahyuningdyah, R. Y. (2018). Efektivitas BI7DRR dalam Kerangka Mekanisme Transmisi Kebijakan Moneter untuk Pengendalian Inflasi. PRAXIS, 1(1), 78-92. https://doi.org/10.24167/PRAXIS.V1I1.1627

Sutawijaya, A. (2012). Pengaruh Faktor-Faktor Ekonomi Terhadap Inflasi di Indonesia. Jurnal Organisasi Dan Manajemen.

Wulandari, N., \& Rahmadeni. (2017). Analisis Faktor-Faktor yang Mempengaruhi Inflasi pada Kota Metropolitan di Indonesia dengan Menggunakan Analisis Data Panel. Jurnal Sains

Statistika. https://doi.org/http://dx.doi.org/10.24014/jsms.v3i2.4475 